\title{
熊本県飽託郡託麻村における, ウシ乳房炎の実態調查成績について
}

\author{
本田多人見* 橋口清治* 神田橋偲* 吉野辰敏* 蔵原久輝* \\ (昭和 42 年 8 月 25 日受付)
}

はじめに

酪農振興に伴い, 農村に扎ける乳牛の飼養頭数は, 年 々增加している. しかし，一方では多頭化と飼盖管理の 省力化が行なわれ, 乳牛の傷病事故による損失も増大し ている事は有利な酪農を経営するため見のがせない問題 であり, 病名別にみると泌尿生殖器病が最も多く, なか でも乳房炎が大半を占めている現状である。

野外に和けるウシ乳房炎の診断には SCHALM らの提晿 した. 迅速で明確な診断が出来る感度の高い, California, mastitis, test (CMT) 飞準拠した，市販乳房炎簡易診断 液（PＬテスター）が広く用いられている．これを使用 した調查成績をみると, 乳牛単位の乳房炎発生頻度は佐 々木ら1), 28/53 (52.8\%), 藤倉 34/65 $\left.(51.5 \%)^{2}\right)$, 阿 形ら3) $48 / 104(46.1 \%), 61 / 113(54.0 \%)$ で, 調查乳牛 の約 $50 \%$ が乳房炎と詪断されている。そこでわれわれ は管内に括㚈る, ウシ乳房炎の罹患状況を把握し, 衛生 指導の一助とするため，P Lテスターを用いて，乳房炎 の実態調査を行なったので，その成績定報告する。

\section{1. 調查地区}

調查地区の乳牛飼養状況は表 1 に示したように，管内 で飼育頭数が最も多い, 飽託郡託麻村全域を選定した, 当村は烟作の酪農地帯で, 昭和 39 年飞農業構造改善事 業の酪農パイロット事業を終了し村内で酪農が最も軌道 に乗った. 日向拉よび北向の両地区と，その周辺に存す る, 小山, 中山地区, そして, その他の供合地区の 4 地 区に分けられる。

調查は村内の酪農家 101 戸に飼養されている搾乳牛, 398 頭を対象に, 昭和 41 年 10 月上旬実施した.

\section{2. 材料和よび方法}

調査対象挖乳牛 398 頭について, 年令, 産歷, 搾乳方
法および過去にお汗る乳房炎罹患状況などの聴きとり調 查, 乳汁の検査, 分離ブドウ球菌の各種楽剤に対する感 受性試験を実施した。

乳汁の採取方法は, 乳頭㐨よび搾乳者の手指をアルニ 一ル綿できれいにふいて, 最初の $2 \sim 3$ 搾りは捨てた 後, 試験管に約 $3 \mathrm{ml}$ あて各分房から竅乳した.

P Lテスターによる検查

乳汁 $1 \mathrm{ml}$ を乳房炎簡易診断用のプラスチック皿にと り, 等量の P Lテスター診断液を加えて静が前後左右 に廻し， 1 分後に凝集と色調を判定基準（表 2)により 乳房炎を診断した.

細菌学的検查

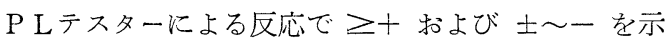
したものについて, 乳汁を各分房ごとに $5 \mathrm{ml}$ あて滅菌 試験管に採取し, 直ちに $5{ }^{\circ} \mathrm{C}$ に保存し, 細菌検查を行な った.

検査に際して乳汁は良く混和して， $0.2 \mathrm{ml}$ あて寒天 平板培地上に接種し $37^{\circ} \mathrm{C}$ 亿 24 ないし 48 時間培養後, グラム染色を行なった．ブドウ球菌の選別には，スタフ イロコッカス 110 培地 (栄研)を用いた.

これらのブドウ球菌について, 家鬼プラズマを用いコ アグラーゼ検査およびマンニット食塩培地でマンニット 分解能の検査を行なった.

感受性試験

分離ブドウ球菌の各種薬剂に対する感受性試験に使用 したデイスクの種類および濃度は（表 3 ）のと拈りであ る.

方法 選別したブドウ球菌をブイヨンに $37^{\circ} \mathrm{C}$ で1夜 培養して, ハートインフユージョン培地に, ピペットで $0.1 \mathrm{ml}$ 抢とし, 隇菌したコンラージ棒で一面に塗りひ ろげ，ピンセットの先を焰で消毒し，デイスクを平板 表 1 調查地区別乳牛飼養状況
（熊本県飽託郡託麻村）

\begin{tabular}{|c|c|c|c|c|c|c|c|c|c|c|c|}
\hline \multirow{2}{*}{ 調查地 } & \multirow{2}{*}{\multicolumn{2}{|c|}{$\begin{array}{l}\text { 飼養戸数 } \\
\text { (A) }\end{array}$}} & \multicolumn{4}{|c|}{ 飼 養 頭 数 (頭) } & \multirow{2}{*}{$\mathrm{B} / \mathrm{A}$} & \multirow{2}{*}{$\mathrm{C} / \mathrm{A}$} & \multirow{2}{*}{$\mathrm{D} / \mathrm{A}$} & \multirow{2}{*}{$\mathrm{B}+\mathrm{C}+\mathrm{D} / \mathrm{A}$} & \multirow{2}{*}{$\begin{array}{l}\text { ミルカー } \\
\text { 普及状況 }\end{array}$} \\
\hline & & & 育成牛(B) & 搾乳牛 (C) & 乾乳牛 (D) & 計 & & & & & \\
\hline 日 & 向 & 31戸 & 65 & 143 & 29 & 237 & 2.1 & 4.6 & 0.9 & 7.6 & $21 / 31(67.7 \%)$ \\
\hline 北 & 向 & 34 & 65 & 134 & 31 & 230 & 1.9 & 3.9 & 0.9 & 6.8 & $29 / 34(85.3 \%)$ \\
\hline 小山, & 中山 & 22 & 39 & 100 & 17 & 156 & 1.8 & 4.5 & 0.8 & 7.1 & $11 / 22(50.0 \%)$ \\
\hline 供 & 合 & 14 & 14 & 48 & 11 & 73 & 1.0 & 3.4 & 0.8 & 5.2 & $7 / 14(50.0 \%)$ \\
\hline 計 & & 101 & $\begin{array}{c}183 \\
(61.1 \%)\end{array}$ & $\begin{array}{c}425 \\
(12.6 \%)\end{array}$ & $\begin{array}{c}88 \\
(26.3 \%)\end{array}$ & $\begin{array}{c}696 \\
(100 \%)\end{array}$ & 1.8 & 4.2 & 0.9 & 6.9 & $68 / 101(67.4 \%)$ \\
\hline
\end{tabular}

* 熊本県中央家畜保健衛生所

日獣会誌 $21 \quad 161 \sim 166 \quad$ (1968) 
表 2 判 定 基 準

A). 凝集拈よび色調（別記判定規準表参照のこと）

\begin{tabular}{|c|c|c|c|}
\hline & $\begin{array}{l}\text { 判 } \\
\text { 定 }\end{array}$ & $\begin{array}{l}\text { 平均白血球 } \\
\text { 数(1cc中方) }\end{array}$ & 所 \\
\hline 凝 & - & 8.8 & $\begin{array}{l}\text { 凝集片を認めず，シャーレーを } \\
\text { 傾けると，牛乳はシャーレーの } \\
\text { 面をスムースに流れる. }\end{array}$ \\
\hline 集 & \pm & 35.0 & $\begin{array}{l}\text { わずかに凝集が認められるが, } \\
\text { 牛乳はシャーレーの面をスムー } \\
\text { スに流れる. }\end{array}$ \\
\hline $\begin{array}{l}\text { なシ } \\
\text { がヤ } \\
\text { らい } \\
\text { 判レ }\end{array}$ & + & 92.1 & $\begin{array}{l}\text { はっきりと凝集が認められ，シ } \\
\text { ヤこレを傾けて集片が表 } \\
\text { 面に残る. }\end{array}$ \\
\hline 定 1 & H & 207.3 & 凝集片多量, 粘稠性がやや強い. \\
\hline る傾 & H & 376.1 & $\begin{array}{l}\text { 凝集片多量, 粘稠性強く半凝塊 } \\
\text { 状 (半ゼリー状) となる. }\end{array}$ \\
\hline & & $\begin{array}{l}\text { 多数のため } \\
\text { 計算不能 }\end{array}$ & $\begin{array}{l}\text { 完全に凝塊状（ゼリー状）とな } \\
\text { る. }\end{array}$ \\
\hline 色 & $\begin{array}{l}\text { 判 } \\
\text { 定 }\end{array}$ & $\mathrm{pH}$ の範囲 & 所 \\
\hline 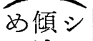 & $(-$ & $6.2 \sim 6.5$ & 黄金色または黄色 \\
\hline $\begin{array}{l}\text { てけ中 } \\
\text { 比牛 }\end{array}$ & \pm & 6.6 & ごくわずかに緑色がかったもの \\
\hline 色乳々 & + & $6.6 \sim 6.8$ & わずかに緑色を呈したもの \\
\hline $\begin{array}{l}\text { すをい } \\
\text { る集を }\end{array}$ & $H$ & $6.8 \sim 7.0$ & 緑色 \\
\hline & 卅 & 7.0 以上 & 濃緑色 \\
\hline
\end{tabular}

B). 総合判定

\begin{tabular}{|c|c|c|c|}
\hline 凝 集 & 色 調 & 判 & 定 \\
\hline- & \multicolumn{3}{|c|}{ 一～土 乳房炎陰性 } \\
\hline $\begin{array}{l}- \\
\pm\end{array}$ & \multicolumn{3}{|c|}{ 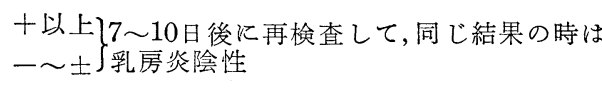 } \\
\hline $\begin{array}{l} \pm \\
+\end{array}$ & \multicolumn{3}{|c|}{$\left.\begin{array}{l}+ \text { 以上 } \\
-\sim \pm\end{array}\right\}$ 乳房炎の疑い } \\
\hline $\begin{array}{l}+ \\
+ \text { 以上 }\end{array}$ & \multicolumn{3}{|c|}{$\left.\begin{array}{l}+ \text { 以上 } \\
-\sim \# \text { 曲 }\end{array}\right\}$ 乳房炎 } \\
\hline
\end{tabular}

面に水平に拈き，かるく拈さえ， $37^{\circ} \mathrm{C}$ のラン器内に入 れ18時間培養した.

判定 沪紙の縁から, $1 \mathrm{~mm}$ 以上の阻止円が出来た場 合 $(+)$

阻止円の広さがそれ以下を阻止円（一）

\section{3. 調査成績}

乳牛を傷病別にみた乳房炎酪農経営を有利に展開する ためには乳牛を傷病事故から守る事が大切である。県下
表 3 感受性デイスクの種類および濃度

\begin{tabular}{|c|c|c|c|c|c|c|c|}
\hline 感デ & ペ & エマ & P & $\eta \simeq$ & テサ & ジスマ & カマ \\
\hline 1 & $=$ & リ & & $D=$ & 1 & ヒトイ & \\
\hline 受六 & シ & スシ & イ & $\begin{array}{l}\text { ラ } \\
\Delta 1\end{array}$ & $\begin{array}{r}\text { トク } \\
\text { リ }\end{array}$ & ドプシ & \\
\hline 性名 & ข & ロン & コン & フル & ラン & ロトン & \\
\hline
\end{tabular}

濃度 $2 \mathrm{U} \quad 2 \mathrm{mcg} 5 \mathrm{mcg} 10 \mathrm{mcg} 10 \mathrm{mcg} 10 \mathrm{mcg} 10 \mathrm{mcg}$

表 4 過去 4 ケ年の乳牛事故頭数

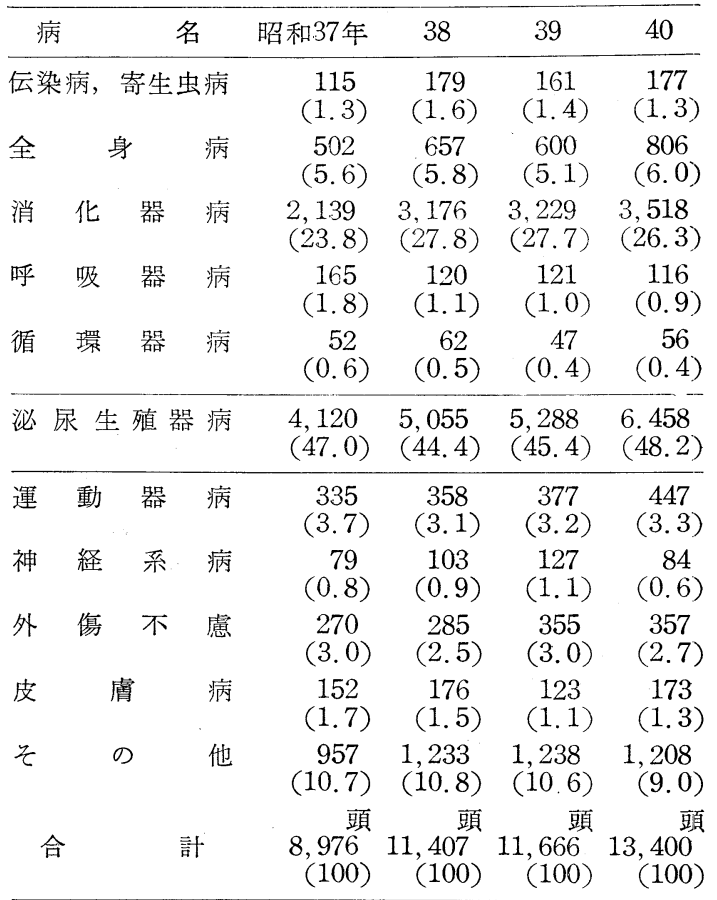

（注）（）内はパーセント （県一円農政課資料） の乳牛について, 事故件数を昭和 37 年から, 昭和 40 年まで病名別にみると表 4 の様に泌尿生殖器病が約45 $48 \%$ で最も多く, 次いで消化器病 $25 \%$, その他の疾病は 10\%以下である。

調査地区に打㺭る乳房炎発生状況は（表 5 ）, 昭和 39 年 294 頭, 昭和 40 年 508頭，前年対比 $173 \%$ ，これら を百分率で月別に乳房焱発生頻度をみると，2 ケ年とも 5 月から 10 月まで上昇し，9１0 月が最高を示してい た。

地区別乳房炎罹患状況

表 5 調査地区に打ける月別の乳房炎罹患状況

\begin{tabular}{|c|c|c|c|c|c|c|c|c|c|c|c|c|c|}
\hline 昭和 & 乳房炎牛 & 4 & 5 & 6 & 7 & 8 & 9 & 10 & 11 & 12 & 1 & 2 & 3 \\
\hline 39 & 294頭(100) & $11(3.7)$ & $17(5.7)$ & $18(6.1)$ & $30(10.2)$ & $32(10.9)$ & $37(12.5)$ & $46(15.6)$ & $30(10.2)$ & $28(9.5)$ & $21(7.1)$ & $13(44)$ & 1) $11(3.7)$ \\
\hline 40 & 508頭(100) & $24(4.7)$ & $28(5.5)$ & $42(8.2)$ & $54(10.7)$ & $47(9.2)$ & $87(17.2)$ & $53(10.5)$ & $52(10.2)$ & $34(6.7)$ & $30(5.9)$ & $26(5.1)$ & 1) $31(6.1)$ \\
\hline
\end{tabular}


本田多人見 橋口清治 神田橋偲 吉野辰敏 蔵原久輝

表 6 調査地区別, 牛群別, おょび㩁乳方法のウシ乳房炎発生状況（昭和41年）

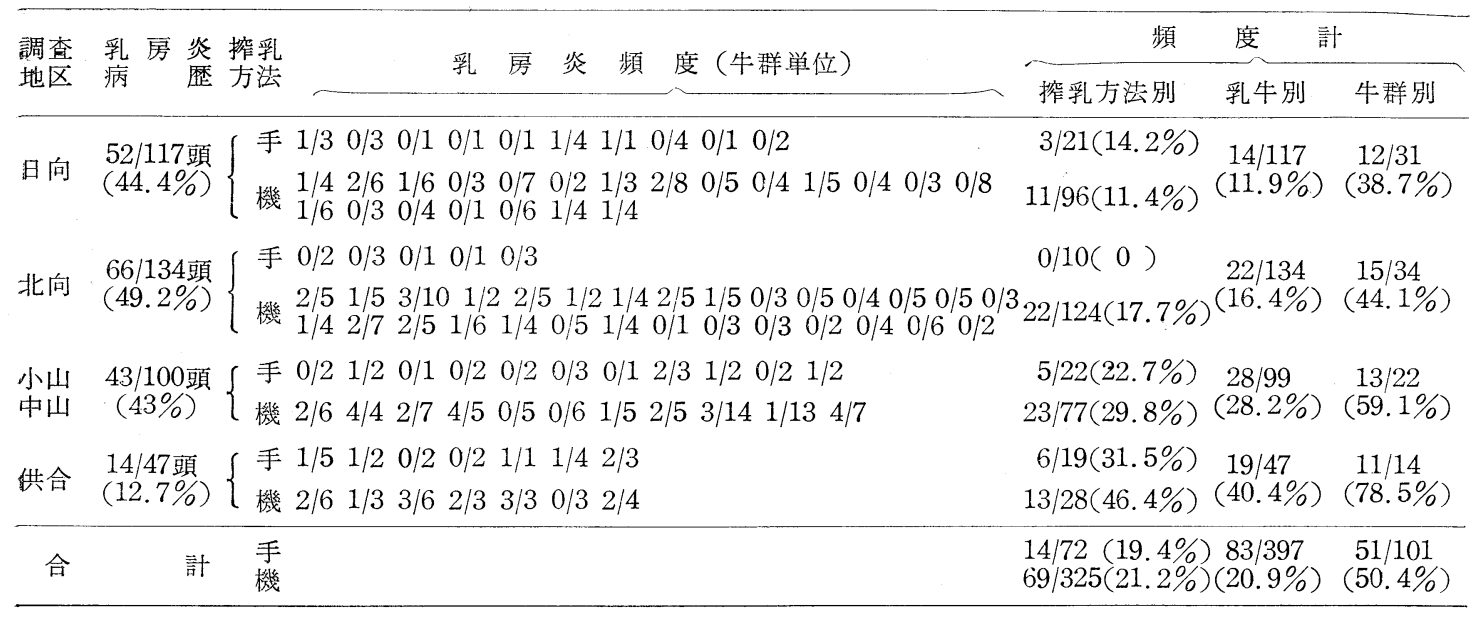

調査地区内に打ける飼養管理の状況は, 酪農パイロッ ト事業を終えた，日向执よび北向の両地区が最も良く， 次いで, 小山, 中山地区乞して供合地区の順である。乳 牛単位の乳房炎罹患状況は（表 6 ）地区により差違がみ られ $(\mathrm{P}<0.001)$ 供合地区は罹患率が最も高く，（0.05 $>\mathrm{P}>0.01)$, 調查地区の平均䍜患率は 83/397 頭 (20.9 \%)であった。 また，牛群別にも地区による差がみられ た $(0.05>\mathrm{P}>0.01)$. 搾乳方法別にみると, 手搾りに よる乳房炎は 14/72 頭 (19.4\%), 機械搾乳による乳房 炎は 69/325 頭(21.2\%) で両者の間には差異がみられな かった（ $\mathrm{P}>0.5)$, しかし地区ごとにみると, 手搾り乳 牛群の差 $(0.2>\mathrm{P}>0.1)$ よりも, 機械搾乳群に打ける 差が著明で $(\mathrm{P}<0.001)$ ミルカーの使用年数が短かい供 合地区は機械搾乳による乳房炎罹患率が最も高かった.

乳房炎罹患状況を分房別にみると（表 7) 手搾りによ る乳房炎は 109/1,300 分房(8.38\%), 機械搾乳による乳 房炎は 21/292 分房 (7.2\%) で両者の間には明らかな差 は見られなかった $(0.3>\mathrm{P}>0.2)$. また両搾乳力法を通 ごて，4 分房の位置による差違も認められなかった（P $>0.5)$.

乳牛 1 個体の乳房资罹患分房を竹乳方法別にみると (表 8 ) 両搾乳方法を通じて $1 \sim 2$ 分房が同時に罹患し

\section{表 7 分房別の乳房炎罡患状況}

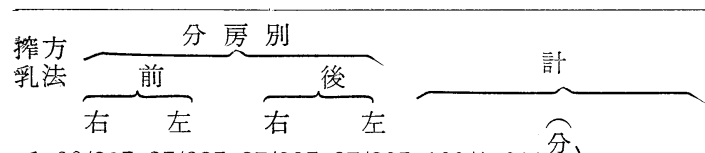
手 $30 / 32525 / 32527 / 32527 / 325 \quad 109 / 1,300$ 分

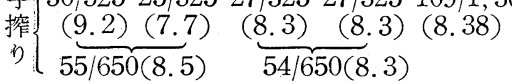

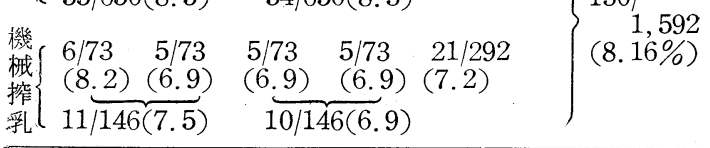

表 8 搾乳方法別にみた乳房炎牛 1 個体中の 羅患分房数比較

\begin{tabular}{|c|c|c|c|c|}
\hline \multirow{2}{*}{$\begin{array}{l}\text { 羅 患 } \\
\text { 分房数 }\end{array}$} & & 搾 乳 & \multirow[t]{2}{*}{ 方 } & \multirow{2}{*}{ 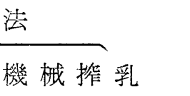 } \\
\hline & & 手 搾 り & & \\
\hline 1 & $13\}$ & \multirow{2}{*}{$14 / 16(87.5 \%)$} & \multirow{2}{*}{\multicolumn{2}{|c|}{$\left.\begin{array}{c}46 \\
10\end{array}\right\} 56 / 68(82.4 \%)$}} \\
\hline 2 & $1\}$ & & & \\
\hline 3 & $2\}$ & \multirow{2}{*}{$2 / 16(12.5 \%)$} & \multirow{2}{*}{\multicolumn{2}{|c|}{$\left.\begin{array}{l}8 \\
4\end{array}\right\} 12 / 68(17.6 \%)$}} \\
\hline 4 & $\int$ & & & \\
\hline 計 & 16 & \multicolumn{3}{|c|}{68} \\
\hline
\end{tabular}

ているのが手搾り $14 / 16$ 分房 (87.5\%) 機械搾乳 56/68 分房 $(82.4 \%)$ で大半を占め, 両者の間には差がみられ なかった $(P>0.5)$.

地区別にみた産次別頭数と乳房炎罹患状況地区ごとの 産次別分布は表 9 の様に, 全地区とも 3 産が最も多く, 5 産以上は急に減少している。これは1個体の搾乳年限が 短かい事を示しているので, もっと経済年限を延長すべ きである. 産次別乳房炎罹患状況は 10 産の 1 例を除い て考劣ると, 産次別には著明な差がタられなかった 0.5 $>\mathrm{P}>0.3)$ が初産〜 2 産の乳牛は $27 / 178$ 頭 (15.1\%) に対し，3 産以上は 57/220 頭(25.9\%) で高かった(0.1 $>\mathrm{P}>0.001)$. 地区別には, 小山, 中山地区は産歴が進 むにつれ乳房炎罹患率の上昇がみられた。

牛群規模別による乳房炎罹患状況 (表10) 搾乳牛を牛 群規模別にみると，8頭以下が 98/101 戸(97.1\%) と大， 部分を占め 10 頭以上は $3 / 101$ 戸 $(2.9 \%)$ の小規模経 営で, 飼養規模別による乳房炎罹患状況には差違がみら れなかった（P>0.5).

細菌検查

細菌検查の対象はP Lテスターの反応 〜ーを示した 84 例について実施したところ（表11）+ を示したもの 45/68 例 (66.2\%) 拈よび 土〜一を示し 
熊本県飽託郡託麻村における，ウシ乳房炎の実態調査成績について

表 9 調查地区別にみた産次別頭数と乳房炎羅患状沉

\begin{tabular}{|c|c|c|c|c|c|c|c|c|c|c|}
\hline 調査地区 & 産 次 & 1 & 2 & 3 & 4 & 5 & 6 & 7 & 10 & 地区別計 \\
\hline 向 & $\begin{array}{l}\text { 頭 } \\
\text { 数 } \\
\text { 乳房炎 } \\
\%\end{array}$ & $\begin{array}{c}27 \\
(23.2) \\
2 / 27 \\
(7.4)\end{array}$ & $\begin{array}{c}25 \\
(21.2) \\
3 / 25 \\
(12)\end{array}$ & $\begin{array}{c}25 \\
(21.1) \\
2 / 25 \\
(8)\end{array}$ & $\begin{array}{c}27 \\
(23.1) \\
6 / 27 \\
(22.2)\end{array}$ & $\begin{array}{c}8 \\
(7.0) \\
1 / 8 \\
(12.5)\end{array}$ & $\begin{array}{c}4 \\
(3.5)\end{array}$ & $\left(\begin{array}{c}1 \\
0.9\end{array}\right)$ & & $\begin{array}{c}117 \\
14 / 117(12 \%)\end{array}$ \\
\hline 向 & $\begin{array}{l}\text { 頭 }{ }^{\text {数 }} \\
\text { 乳房炎 } \\
\%\end{array}$ & $\begin{array}{c}30 \\
(22.4) \\
2 / 30 \\
(6.6)\end{array}$ & $\begin{array}{c}39 \\
(29.1) \\
6 / 39 \\
(15.4)\end{array}$ & $\begin{array}{c}42 \\
(31.3) \\
12 / 42 \\
(28.6)\end{array}$ & $\begin{array}{l}12 \\
(9.0) \\
0 / 12\end{array}$ & $\begin{array}{c}6 \\
(4.5) \\
1 / 6 \\
(16.6)\end{array}$ & $\begin{array}{c}4 \\
(3.0)\end{array}$ & & $\begin{array}{l}1 \\
(0.7) \\
1 / 1 \\
(100)\end{array}$ & $\begin{array}{c}134 \\
22 / 134(16.4 \%)\end{array}$ \\
\hline 小山, 中山 & $\begin{array}{l}\text { 頭 } \\
\text { 数 } \\
\text { 乳房炎 } \\
\%\end{array}$ & $\begin{array}{c}19 \\
\left(\begin{array}{c}19 \\
5 / 19\end{array}\right) \\
(26.3)\end{array}$ & $\begin{array}{l}25 \\
(25) \\
5 / 25 \\
(20.0)\end{array}$ & $\begin{array}{c}28 \\
(28) \\
5 / 28 \\
(17.9)\end{array}$ & $\begin{array}{c}14 \\
(14) \\
6 / 14 \\
(42.9)\end{array}$ & $\begin{array}{l}6 \\
\left(\begin{array}{c}6 \\
3 / 6\end{array}\right) \\
(50)\end{array}$ & $\begin{array}{c}6 \\
\left(\begin{array}{c}6 \\
4 / 6\end{array}\right) \\
(66.6)\end{array}$ & $\left.\begin{array}{c}2 \\
2 \\
1 / 2 \\
50\end{array}\right)$ & & $\begin{array}{c}100 \\
29 / 100(29.0 \%)\end{array}$ \\
\hline 供 & $\begin{array}{l}\text { 頭 } \\
\text { 数 } \\
\text { 乳房炎 } \\
\%\end{array}$ & $\begin{array}{c}5 \\
(10.6) \\
0 / 5\end{array}$ & $\begin{array}{c}8 \\
(17.0) \\
4 / 8 \\
(50)\end{array}$ & $\begin{array}{c}14 \\
(29.8) \\
7 / 14 \\
(50)\end{array}$ & $\begin{array}{c}11 \\
(23.4) \\
6 / 11 \\
(54.5)\end{array}$ & $\begin{array}{c}3 \\
(6.4) \\
1 / 3 \\
(33.3)\end{array}$ & $\begin{array}{c}6 \\
(12.8) \\
1 / 6 \\
(16.7)\end{array}$ & & & $\begin{array}{c}47 \\
19 / 47(4\end{array}$ \\
\hline 産次別合計 & $\begin{array}{l}\text { 頭 } \\
\text { 数 } \\
\text { 乳房咨 } \\
\%\end{array}$ & $\begin{array}{c}81 \\
(20.4) \\
9 / 81 \\
(11.1)\end{array}$ & $\begin{array}{c}97 \\
(24.4) \\
18 / 97 \\
(18.5)\end{array}$ & $\begin{array}{c}109 \\
(27.4) \\
26 / 109 \\
(23.8)\end{array}$ & $\begin{array}{c}64 \\
(16.1) \\
18 / 64 \\
(28.1)\end{array}$ & $\begin{array}{l}23 \\
(5.8) \\
6 / 23 \\
(26)\end{array}$ & $\begin{array}{l}20 \\
(5.1) \\
5 / 20 \\
(25)\end{array}$ & $\begin{array}{c}3 \\
(0.8) \\
1 / 3 \\
(33.3)\end{array}$ & $\begin{array}{c}1 \\
1 / 1 \\
(100)\end{array}$ & $\begin{array}{l}398 \\
84 / 398(21.1 \%)\end{array}$ \\
\hline
\end{tabular}

表10 調査地区別にみた牛群規模による乳房炎羅患状況

\begin{tabular}{|c|c|c|c|c|c|c|c|c|c|c|}
\hline \multirow[b]{2}{*}{$\begin{array}{l}1 \text { 牛群の } \\
\text { 乳牛頭数 } \\
\text { (牛群規模) }\end{array}$} & \multicolumn{2}{|c|}{ 北 向 } & \multicolumn{2}{|c|}{ 日 向 } & \multicolumn{2}{|c|}{ 小山, 中山 } & \multicolumn{2}{|c|}{ 供 合 } & \multirow{2}{*}{ 総 } & \multirow[b]{2}{*}{$\begin{array}{l}\text { 戸 } \\
\text { 数 }\end{array}$} \\
\hline & $\overbrace{01234}^{\text {乳房炎頭数 }}$ & $\begin{array}{c}\begin{array}{c}\text { 頻度計 } \\
(\%)\end{array} \\
(\%)\end{array}$ & $\overbrace{01234}^{\text {乳房炎頭数 }}$ & $\begin{array}{cc}\text { 頻度計 } \\
4 & (\%)\end{array}$ & $\overbrace{0123}^{\text {乳房炎頭数 }}$ & 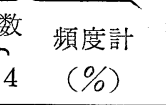 & $\overbrace{01234}^{\text {乳房炎頭数 }}$ & 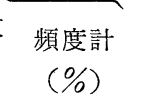 & & \\
\hline 1 & 51 & $1 / 6(16.7)$ & 3 & $0 / 3$ & 2 & $0 / 2$ & 1 & $1 / 1(100.0)$ & $2 / 12(16.6)$ & 12 . \\
\hline 2 & 2 & $0 / 4$ & 32 & $2 / 10(20.0)$ & 24 & $4 / 12(33.3)$ & 21 & $1 / 6(16.7)$ & $7 / 32(21.8)$ & 16 \\
\hline 3 & 42 & $2 / 18(11.1)$ & 6 & $0 / 18$ & 1111 & $3 / 9(33.3)$ & 1121 & $8 / 15(53.3)$ & $13 / 60(21.6)$ & 20 \\
\hline 4 & 44 & $4 / 32(12.5)$ & 24 & $4 / 24(16.7)$ & & $14 / 4(100.0)$ & 11 & $3 / 8(37.5)$ & $15 / 68(22.0)$ & 17 \\
\hline 5 & 11 & $1 / 10(10.0)$ & 424 & $10 / 50(20.0)$ & 111 & $17 / 20(35.0)$ & 1 & $1 / 5(20.0)$ & $19 / 85(22.3)$ & $17^{\circ}$ \\
\hline 6 & 121 & $4 / 24(16.7)$ & 11 & $1 / 12(8.3)$ & 11 & $1 / 12(8.3)$ & 11 & $5 / 12(41.7)$ & $11 / 60(18.3)$ & 10 \\
\hline 7 & 1 & $0 / 7$ & 1 & $2 / 7(28.6)$ & 1 & $16 / 14(42.9)$ & & & $8 / 28(28.5)$ & 4 \\
\hline 8 & 11 & $2 / 16(12.5)$ & & & & & & & $2 / 16(16.6)$ & 2 \\
\hline $\begin{array}{r}9 \\
10\end{array}$ & & & 1 & $2 / 10(200)$ & & & & & $3 / 10(300)$ & 1 \\
\hline 11 & & & & $0 / 10(00.0)$ & & & & & $0 / 10(30.0)$ & \\
\hline 12 & & & & & & & & & & \\
\hline 13 & & & & & 1 & $1 / 13(7.7)$ & & & $1 / 13(7.7)$ & 1 \\
\hline 14 & & & & & 1 & $3 / 14(21.4)$ & & & $3 / 64(21.4)$ & 1. \\
\hline & & $4 / 117(12.0)$ & & $22 / 134(16.4$ & & $29 / 100(29.0)$ & & $19 / 47(40.4)$ & $84 / 398(21.1)$ & \\
\hline
\end{tabular}

表11 乳汁中ょりの細菌分離成績

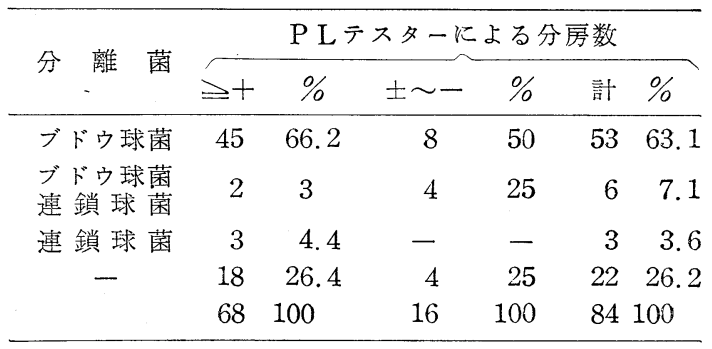

たもの 8/16 例 $(50 \%)$ からグラム陽性のブドウ 球菌が 分離出来たが，分離頻度においてはこれらの間には著る

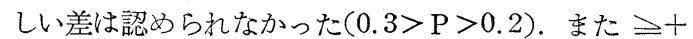
を示しながらブドウ球菌が全く認められなかったものが. 18/68 例 $(26.4 \%)$ あった.

乳汁中より分離したブドウ球菌の各種薬剤に対する耐 性 (表12).

ブドウ球菌の分離率は地区による著るしい差違はみら れず $(0.5>\mathrm{P}>0.3)$, 分離出来た 53 株のブドウ 球菌 中，コアグラーゼおよびマンニット分解能陽性のいわゆ る病原性ブドウ球菌の性状を有するものは 7/53 株(13.2 \%)に認められたが乳房炎病歴牛の最も少い(14/47 頭, $12.7 \%$ ）供合地区からは認める事が出来なかった. 
本田多人見 橋口清治 神田橋偲 吉野辰敏 藏原久輝

表12 乳汁中より分離したブドウ球菌の各種薬剤に対する耐性（昭和 41 年）

\begin{tabular}{|c|c|c|c|c|c|c|c|c|}
\hline \multirow{2}{*}{$\begin{array}{l}\text { 調 } \\
\text { 查 } \\
\text { 地 } \\
\text { 区 }\end{array}$} & \multirow{2}{*}{$\begin{array}{l}\text { ブドウ } \\
\text { 球菌分 } \\
\text { 離 }\end{array}$} & \multirow{2}{*}{$\begin{array}{l}\text { コマグラーゼ } \\
\text { 反応およびマ } \\
\text { ンット分解 } \\
\text { 能陽性菌 }\end{array}$} & \multicolumn{5}{|c|}{ 単剤ないし多剤耐性 } & \multirow{2}{*}{$\begin{array}{l}\text { 薬㶡酎性 } \\
\text { 頻 度 }\end{array}$} \\
\hline & & & 1 & 2 & 3 & 4 & 5 & \\
\hline 日向 & $\begin{array}{r}6 / 12 \\
(50 \%)\end{array}$ & 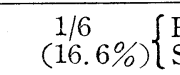 & $\begin{array}{l}\text { P C } 2 \\
\text { S M } 1\end{array}$ & & & & & $\begin{array}{c}3 / 6 \\
(50 \%)\end{array}$ \\
\hline 北向 & $\begin{array}{l}12 / 20 \\
(60 \%)\end{array}$ & $(16.6 \%)\left\{\begin{array}{l}\mathrm{H} \\
\mathrm{E} \\
\mathrm{I} \\
\mathrm{S}\end{array}\right.$ & $\begin{array}{l}\text { P C } 2 \\
\text { EM } 1 \\
\text { LM } 1 \\
\text { S M } 2\end{array}$ & & P C. EM. LM 1 & & & $\begin{array}{c}7 / 12 \\
(58.3 \%)\end{array}$ \\
\hline $\begin{array}{l}\text { 小山 } \\
\text { 中山 }\end{array}$ & $\begin{array}{l}24 / 38 \\
(63.2 \%)\end{array}$ & 6) $\left.\begin{array}{c}4 / 24 \\
(16.6 \%\end{array}\right)\left\{\begin{array}{l}\mathrm{I} \\
S\end{array}\right.$ & $\begin{array}{l}\mathrm{PC} 3 \\
\mathrm{SM} 2\end{array}$ & $\begin{array}{l}\text { P C. T C } 1 \\
\text { P C. SM } 1\end{array}$ & $\begin{array}{l}\text { PC. EM. SM } 1 \\
\text { PC. EM. LM } 4\end{array}$ & PC. EM. LM. SM 1 & $\begin{array}{l}\text { PC. EM. LM- } \\
\text { TC. SM } 1\end{array}$ & $\begin{array}{l}-14 / 24 \\
(58.3 \%)\end{array}$ \\
\hline 供合 & $\begin{array}{l}11 / 13 \\
(84.6 \%\end{array}$ & б) $\left(\begin{array}{c}0 / 11 \\
0\end{array}\right)$ & EM 1 & & & & & $\begin{array}{l}1 / 11 \\
(9.0 \%) \\
\end{array}$ \\
\hline 合計 & $\begin{array}{l}53 / 83 \\
(63.9 \%) \\
(\text { 株 })\end{array}$ & $\begin{array}{l}7 / 53 \\
\text { 6) }(13.2 \%) \\
(\text { 株 })\end{array}$ & 15 & 2 & 6 & 1 & 1 & $\begin{array}{l}25 / 53 \\
(47.1 \%)\end{array}$ \\
\hline
\end{tabular}

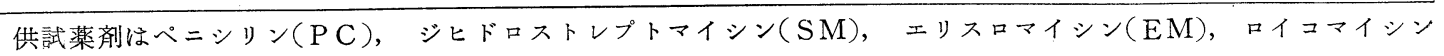
( L M ), およびテトラサイクリン( T C ).

また分離したブドー状球菌の各種薬剂に対する感受性 について調べたところ 25/53 秼( $47.1 \%$ )が耐性を有し地 区により明らかな差違が認められた $(0.05>\mathrm{P}>0.001)$, 1 剂に耐性を示したものは PC, SM, EM, LMが 7, 5, 2, 1 株，2 剂に耐性は PC-TC, PC-SM が各々 1 株, 3 〜 剂耐性は 8 株認められた.

供試剂 7 剂中，全く耐性が認められなかった薬剂は CM と KM であった.

\section{考察}

野外におけるウシの乳房炎浸潤状況調査は各地で行な われ報告されている1〜4)。今回われわれは，管内の搾乳 牛がどれ位乳房炎に羅患しているかについて, 聞き取り 調査, 乳房炎簡易診断液（PＬテスタ一）を用いて乳房 炎の罹患状沉調查と細菌学的検査を行なったところ, 乳 牛の傷病中, 淰尿生殖器病の占める割合は非常に高く, 月別の乳房炎発生頻度は, 冬季よりも気温が上昇する夏 から秋にかけて頻度が高い傾向がみられた，調査地区の 乳房炎罹患状況は 83/397 頭(20.9\%) で, 藤倉, 佐々木 らの調查成績に比べると低率であった．地区別にみると 乳牛別括よび牛群別に差がみられ $(0.05>P>0.001)$ ， 搾乳方法別には差がみられなかった（P>0.5)，これは 藤倉, 佐々木らの成績と相違していた。機械搾乳群は地 区ごとの乳房炎罹患状況に差がみられ $(P>0.001)$, ミ ルカーの普及後間もない地区は，機械搾乳による乳房炎 が高く, 今後ミルカーの使用法に一考を要する. 分房単 位別にみると搾乳方法別および分房の位置による差は認 められず，1個体中の乳房炎罹患分房は 1 ～分房が同 時に罹患しているのが約 $80 \%$ で，搾乳方法別による差 は認められなかったが，地区別には機械搾乳の方が広く 罹患していた.
乳汁由来のブドウ球菌は 45/68 例 $(66.2 \%)$ に認めら れ, 藤倉, 佐々木らの調查成績 $(80 \%)$ に比べると低率 で，PLテスターの反応が き十拈よび士〜一を示し たものから $66.2 \%, 5.0 \%$ にブドウ球菌が認められ, 両 者の間には著るしい差がなく $(0.3>\mathrm{P}>0.2)$ 反応がー にもブドー状球菌の存在が認められた.コアグラーゼお よびマンニット分解能陽性のブドウ球菌は 7/53 株 $(13.2$ \%)に認められ, 極めて低率で, 地区により差違があ り, 過去にお活る乳房炎病歴牛の罹患頻度が低い地区に は認められなわった，なた，各種薬剤に対する耐性頻度 は25/53 株 (49.1\%) で地区により明らかな差がみら れ, 産歴が進むにつれ, 乳房炎罹患率が高かった地区は 同時に数種類の薬丳に対し耐性を示し，P Lテスターに 高率に反応し，コアグラーゼ拈よびマンニット分解能㓌 性のブドウ球菌検出率が高かった地区はわづか 1 剂に耐 性を示したに過ぎなかった。

供試薬剤中，全く耐性が認められなかったのはクロラ ムフェニコールとカナマイシンであった.

\section{むす び}

今回の調査は初めての試みとして実施したので要を得 ていない点も多々あるが, 管内における乳房炎の罹患状 況を把握するため調査したところ, 乳房炎罹患率, 乳汁 由来のブドウ球菌および薬剤に対する耐性はそれ程まで 高くない結果を得, 今後の乳房炎対策上参考となった. 次回からはさらに乳房炎罹患率の高い地区を中心に, 診 断と治療対策を推進して行きたいと思う.

（本論文の要旨は, 昭和 42 年 1 月 19 日九州地区家畜 保健技術研究会に㧅いて発表した）

本調査のため多大の御協力をいただいた，託麻村 役 場, 小山, 戸島農協, および託麻東部農業改良普及所の 各位に謝意を表します。 
一養鵎場に打けるニューカッスル予防注射と発生状沉

また，本稿を終るにあたり，終始，御指導と御鞭撻を 賜わった。農林省家畜衛生試験場第 1 研究部長, 柴田重 孝博士に深謝します。

文献

1) 佐々木, 鈴木, 阿形, 大庭, 大須賀, 名倉, 藤倉 : 日獣会誌. 17，11，586（1964）。 2) 藤倉：獣医畜産 新報, No.429，905 (1966). 3) 藤倉 : 獣医畜産新報,
No. 431，1,025 (1966). 4) 阿形, 藤倉 : 畜産の研究, 20，8，1,069 (1966). 5) 藤倉 : ベテリナリアン, 3, 5, 49 (1967). 6) 藤倉, 柴田, 阿形, 篠崎, 大井, 大庭, 名倉, 大須賀, 佐々木, 藤井: 家畜用ニトロフラ ンに関する資料，5，4，1（1965). 7) 家畜衛生試験 場年報, 308, 昭和 36,37 年. 8) 家畜衛生試験場年報, 64 , 昭和 38 年.

\title{
一養鵎場に括けるニユカッスル予防注射と発生状況
}

\author{
井上 勇* 野本貞夫* 渡辺文男* 五十里正秋**
}

（昭和 42 年 5 月 20 日受付）

埼玉県に括けるアジア型ニューカッスル病（以下ニュ 一カッスル病はND と略) の発生は, 1966年5月に初発 しその後小康を保っていたが同年暮より 1967 年にかけ て各地で発生し, その後は爆発的な流行がみられ養鵎家 を脅威のどん底におとしいれた。

従来 NDの予防は, 不活化ワクチンの予防注射により ア・メリカ型の NDに対してはほぼ満足すべき成果をあげ てきたが，今回のアジア型流行に際し予防効果がかなら ずしも効果的でなく, 完全に予注が実施してあるにもか かわらず発生へい死する症例が多発した。このように不 活化ワクチンの予防効果について疑義が生じ，そのため 早急な再検討の必要が痛感された。

そこで, 不活化ワクチンの予防効果がアジア型に対し て実際にどの程度であるのか, 一発生養鵎場を対象とし 調査を実施したので概要を報告する.

\section{発生概況}

飼育羽数は, 産卵鶏約 6,000 羽, 育成雊約 2,250 羽, 合計約 8, 250 羽で, 大部分がハイライン種である.雊は毎 月約 500 羽導入して育㮲し, 飼料は昭和産業株式会社の 完全配合飼料を給飼していた。 また, 鶏舎の配置は図 1 のとおりで産卵鶏は主として 2 段のひな段複飼ケージで 飼育されていた。

昭和 42 年 1 月 31 日, No. 7 の鶏群が食欲不振とな り, 採食量は $1 / 3$ 量に減少した. そして, 緑便や乳灰白 下痢便が認められた. 奇声や神経症状は認められなかっ た. 畜主は 38 羽にストレプトマイシンを1羽あたり $100 \mathrm{mg}$ ずつ注射し裏山に隔離を行なった.

2 月 2 日にいたりさらに No. $5,6,8$ の産卵鶏が食欲 の減退を示し始め, 2 月 3 日には食欲は半減した。 それ と同時に乳白色や鮮明な緑色下痢便が観察され， 2 月 6 日には産卵は急激に減少した。 また，2月 6 日にはNo. 1, 2, 3, 4 の各鵎群が食欲半減し, 他の群にも散発が

\footnotetext{
* 埼玉県家畜衛生試験場

** 埼玉県中央家畜保健衛生所
}

認められた。 また夜間，ケーケーの奇声が著明に聞える ようになった。

\section{現症}

2 月 10 日, 現地調査の際にみられた臨床症状はつぎ のとおりであった.

No. 6 (486羽), 7 (298羽), 8 (145羽) の鶏群はすで に処分されており，ヶージ内には鷄はいなかったが床に は鮮明な緑色と灭白色下痢便が認められた。また他の鶏 群にも同様な所見が散発的に観察され, ーーケーの奇声 も聞えた．鶏群は図1のと拈り 28 の群に分れていた が，そのらち D, E, G, H, I, J 群には症状は認められ なかった。

へい死した 5 羽 (No. 5 群) につき剖検を実施したと ころ, 腺胃粘膜の出血点, 脾の腫大と乍白色点, 泗巣の 不整卵胞と血腫卵形成が認められ病理解剖学的にアジア 型 NDであると判定された.

\section{調 査 方 法}

鶏群の選定 : 鶏群は 28 の群に分れており, 鶏群間の 移動, ND 予注月日の失念等があったため調査鵎群の選 定にあたってはつぎの点に留意した。すなわち同一餒化 月日, 同一種類, ND 予注実施月日の確実な舀群だけを 調査対象とし，ND 予注効果を比較するため，未注 射 群，抗体産生前の鶏群， 1 回注射， 2 回注射および 3 回 注射鵎群, 症状出現の有無等を考慮してそれぞれ選定し た. 調査対象群は表 1 に示した。

臨床症状 : 群別に, 元気, 採食等一般症状, 便の状態, 奇声, 神経症状およびへい死の状況について観察した.

産卵調査： 2 月 10 日より 3 月 27 日まで 46 日間群 別に調査を行ない，産卵率はヘンデー計算で行なった.

HI-test：No. 1，4，14，J，B群につき各群 7 羽ずつを 対象とし，4回にわたり個体別に実施しH I 抗体価の消 長について観察した。

以上の成績を総合して，不活化ワクチンの予防効果に 